\title{
Traditional Knowledge and Use of Rock Pools in the Brazilian Caatinga: Memory and Identity in Temporary Ecosystems
}

Luciana Gomes Barbosa ( Igomesbarbosa@gmail.com )

Paraiba Federal University: Universidade Federal da Paraiba https://orcid.org/0000-0002-2245-6119

João Paulo de Oliveira Santos

Paraiba Federal University: Universidade Federal da Paraiba

Kelly Dayane Pereira da Silva

Paraiba Federal University: Universidade Federal da Paraiba

Núbia da Silva

Paraiba Federal University: Universidade Federal da Paraiba

Ismael Romão dos Santos

Paraiba Federal University: Universidade Federal da Paraiba

Reinaldo Farias Paiva de Lucena

Paraiba Federal University: Universidade Federal da Paraiba

Research

Keywords: Blooms, Ethno-limnology, Dry lands zones, Water quality

Posted Date: November 12th, 2020

DOI: https://doi.org/10.21203/rs.3.rs-103980/v1

License: (c) (i) This work is licensed under a Creative Commons Attribution 4.0 International License. Read Full License 


\section{Abstract}

Background

Memory is a collective ownership based on facts and past events. Aristotle and Agostinho were the first philosophers to investigate it, including the dimensions of time and memory inhabited by man. Northeastern Brazil has a rich cultural history linked to water scarcity in the region, one of the main limiting factors to the development of rural populations. Among alternative sources, temporary ecosystems known as rock pools have been used as rainwater storage in arid and semiarid regions around the world. Considering the hypothesis that the arrival of perennial water sources can impact memory transmission between generations, this study aimed to analyze the popular knowledge about rock pools, a traditional and ancient water source.

Methods

Information about the use and management of rock pools in the Brazilian semiarid region was collected by interviewing residents from a small city near an inselberg. The interviews presented specific questions about the structure, characteristics, traditional knowledge, use and management of rock pools. During sampling, 20 rock pools were visited by two key informants, i.e., those with more experience and knowledge about these ecosystems.

Results

Our results identified that the use and management of rock pools were reduced after the Brazilian government implemented the One Million Cisterns Project. Therefore, despite the historical relevance of these water bodies, their uses were forgotten by most of the inhabitants and those from neighboring locations, remaining for domestic use.

\section{Conclusions}

Results about traditional knowledge indicated that the generation interviewed still remembers such method. However, with the presence of cisterns, the transmission of traditional knowledge about rock pools has decreased between the families and generations, presenting a serious social risk for a region characterized by extreme and prolonged droughts.

\section{Background}

Historically, several authors have sought to understand the mechanisms of memory transfer between generations. Among the leading researchers, Aristotle and Agostinho established the pillars for this concept. Agostinho assigned memory as a key component of knowledge and emotions, whereas Aristotle developed the role of paste memories on the exercise of thinking [1, 2]. In this sense, memory is a great treaty of the past, establishing bridges between different generations and connecting a collective and individual past [3].

The main aspects of colonization of ancient people on Earth have been associated with water distribution. The development of the first civilizations indicates the relevance of water, especially in regions where this resource is scarce. In Australia, one of the world's driest continents, water was an essential factor for the development of Aboriginal social, economic, and religious aspects [e.g. 4]. Aboriginal people describe "living water" as a permanent source [5], while seasonal waters are associated with the dry periods and are sometimes stochastic and irregular in dryland regions. These elements of the aboriginal heritage highlight a close relationship between the native people and water, an important symbol that influences their current artistic esthetic [6] and has affected the colonization of ancient people. Climate change studies about the stability of ecosystems in Brazil indicate that the Caatinga is among the most vulnerable globally, with strong desertification pressure in the region $[7,8,9]$. Despite the equatorial geographical position, the region's climate is hot semiarid with average annual temperatures around 24.5 ${ }^{\circ} \mathrm{C}$ [e.g., 10]. Therefore, the climate is characterized by large interannual variability alternating between prolonged droughts and short rainfall periods, resulting in significant rainfall deficit [9] and effects on the socioeconomic dynamics [11]. In the past, rain fall has been interrupted or intensified by climate phenomena such as El Niño, prolonging drought periods $[12,13]$. 
The financial structure of family farmers from the semiarid region has now been weakened by rainfall reduction and prolonged drought periods, which have been registered at least once every decade [14]. The climate change scenario indicates alarming projections for the arid and semiarid regions, with an increase in temperatures and reduction in water availability, inducing an expansion of these areas on a global scale [15] and reducing access to water in regions such as South Africa, Mar Aral region, and Australia [16].

Despite reduced water availability, the residents in dry land zones have not fall in victim to climate change, exhibiting high resilience, collaborative communities, and strengthening themselves against natural disasters and climate change consequences [17]. In addition, these populations might also develop an organized structure to face climate change consequences that guarantee basic livelihoods through the five areas, including human, social, physical, financial, and natural resources [18]. Evaluating the dynamic of these areas may help to identify possible solutions to climate change effects [19].

Among the main strategies adopted by the populations, rainwater and storage technologies are essential for the development of dry land regions around the world. Thus, while the state politically allocates resources, the population develops techniques to deal with water shortage situations through traditional knowledge [20]. Among the main traditional storage technologies, rock pools inserted into rocky, crystal-based fissures represent a natural source of rainfall storage [21], including all temporary depressions found in rocky substrates that accumulate freshwater [22].

For many years, traditional communities have used these reservoirs for different purposes, such as human and animal consumption, domestic and agricultural use, as well as for maintaining small rural areas [23, 24]. to Andrade et al. [25], rock pools are a common structure in inselbergs, acting as rainwater collection depository. The water storage was used for human supply, ensuring water safety for the rural populations.

Considering the potential threat scenarios caused by global warming and climate change, the present study aimed to analyze the traditional knowledge transmission and rock pool use in a rural community in the Brazilian semiarid region. We hypothesize that the knowledge transmission of techniques between generations has reduced after the arrival of new technologies associated with water supply.

\section{Methods}

\section{Study area}

The rural community Rio Direito ( $7^{\circ} 21^{\prime} 32,68^{\prime \prime} \mathrm{S}, 7^{\circ} 36^{\prime} 04,86^{\prime \prime} \mathrm{W} ; 36^{\circ} 11^{\prime} 36,54^{\prime \prime} \mathrm{S}, 36^{\circ} 26^{\prime} 17,48^{\prime \prime} \mathrm{W}$ ) is located in Paraiba state (Brazil), in the mesoregion of Borborema and the microregion of Eastern Cariri (Figure 1). Situated in the Paraíba River hydrographic basin, the main water bodies are intermittent, with a dendritic drainage pattern throughout the Taperoá, Paraíba and Boa Vista Rivers [26]. The highly seasonal variation of precipitation and predominance of shallow soils inserted into crystalline rocks cause low water exchange between the reservoir and adjacent soil [27]. The climate is hot semi-arid (BSh) [10], with mean annual temperature of $>20^{\circ} \mathrm{C}$ and the lowest mean annual rainfall in Brazil, which was $\leq 77.3 \mathrm{~mm}$ during the sampling period [28].

The community of Rio Direito is a small village, where villagers are mostly older people who are retired, farmers, or cattle ranchers. The main activities are the cultivation of corn, beans, palm or goat and cattle farming. Another common economic activity in the region is the production and sale of coal.

\section{Data collection}

Water samples were collected from the subsurface, from which the transparency $(\mathrm{m})$, temperature $\left({ }^{\circ} \mathrm{C}\right), \mathrm{pH}$, dissolved oxygen $\left(\mathrm{mg} . \mathrm{L}^{-1}\right)$, turbidity and total dissolved solids were measured "in situ". The vertical light attenuation coefficient ( $\mathrm{k}$ ) was calculated through the relation $\mathrm{k}=1.7 \times \mathrm{Z}_{\mathrm{DS}}{ }^{-1}$ [29]. The euphotic zone (Zeu) was calculated by multiplying the value obtained by the Secchi disk (10\% incidence of light) by 2.7 [30]. 
Phytoplankton samples were fixed with Lugol's solution. Phytoplankton quantification was performed according to Utermöhl [31], and sedimentation time following Lund et al. [32]. Biomass $\left(\mathrm{mg} \mathrm{L}^{-1}\right)$ was estimated through biovolume [33 and 34 ].

\section{Analyses}

The dynamics of use and management of rock pools were determined by interviewing all residents in the Rio Direito River between January and February 2015. All residents were asked to sign the Informed Consent, which was requested by the National Council for Health through the Research Ethics Committee (REC) (196/96). The ethics committee at the Wanderley Lauro Hospital of the Federal University of Paraíba approved the present study (ECR/HULW n² 297/11).

In total, 15 informants between ages 34 and 81 ( 6 men and 9 women) participated in the interviews. The survey used in the interviews presented specific questions about the concept, characteristics, use and management of rock pools. The interview was structured to avoid inducing answers and to obtain more accurate information as interviewees were able to speak freely about the proposed topics. During sampling, 20 rock pools were visited by two key informants, i.e., those with more experience and knowledge about these ecosystems. The information obtained was analyzed using compared cognition tables [35].

\section{Results}

\section{Physical and Chemical scenario}

All rock pools were classified as shallow $(\leq 5 \mathrm{~m})$, with warm and mixed waters $\left(\leq 36.7 \mathrm{C}^{\circ}\right)$ and low light availability (Zeu : Zmix $\leq 1)$ was observed. The $\mathrm{pH}$ values ranged from acidic to slightly alkaline $(\leq 10.2)$ (Table 1$)$.

We identified 55 species and morph species; the highest biomass from the phytoplankton community was associated with

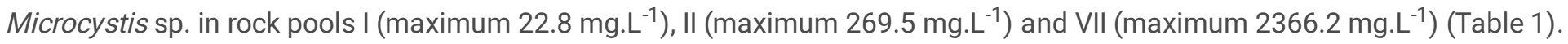
In the absence of Microcystis sp., Chlorococcales were dominant (XV and XIII). Submerged macrophytes (Chara martiana J. Wallman) were only found in VIII and IX, which coincided with the highest values of $Z_{\text {eu }}: Z_{\text {mix }}(\leq 1)$ (Figure 2).

\section{Traditional knowledge and Rock pool use}

For many decades, the Rio Direito community has been witnessing a series of changes since rock pools were introduced. One of the most important historical events occurred when emergency rock pools were constructed, which elderly people reported as a project created and maintained by the government.

Besides the construction of these ecosystems, other ecosystems emerged that received specific names, as reported by some informants.

The deepest Lagoa da Cobra;

As well as Lagoa da Batata,

Lagoa da Mucunã, Baixa detrás da lagoa, Piscina, Lagoa Velha,

Tanque de Severino Tito, Tanque Inácio Roberto,

Cortume de Maria Simão, Baixa do Anel, Tanque Baixa de Rita,

Baixa de Tia Francisca, Tanque de Santo Moura, Baixa de Alexandrina,

Loca de Lotero, Baixa escondida, Tanque do Pereiro, Tanque da Caubêira,

Tanque dos Nêgro. (R,M.F, 81)

Page $4 / 16$ 
Here we have twenty rock pools, some big,

others not, some are very shallow and will dry up soon,

the deepest ones last longer...

(R. F, 48)

Among the management techniques to reduce water evaporation, residents reported the use of wood (so-called stake) and stones. The main objective was to prevent animals, leaves, and twigs from entering the rock pools, favoring increased water quality (Figure 3). Most people understood water quality concepts well and how to correctly apply them (Table 2), specifically about watercolor. One common association was low water quality with green colored rock pools. In general, the green color was correlated to cyanobacteria blooms (Table 1). Overall, the residents did not recognize floral diversity, calling all species (or biological groups) sludge or paste.

In the present study, cisterns were more commonly used than rock pools. Thus, some informants reported cisterns as the best water storage method:

"In cisterns the water is cleaner than in rock pools" (J.C.F, 44).

According to informants, the use and management of rock pools were reduced after the implementation of the governmental programs, among these the P1MC (One Million Cisterns Project). The quality of life of inhabitants in the Rio Direito has improved, and rock pools have been forgotten about by most of its inhabitants and those from neighboring locations, remaining for domestic uses such as laundry and consumption (Table 3). Regarding the water used, over time water has been used for domestic activities, farming and livestock and human supply. The farmers had their own perspective about water quality, including sweet taste and transparency, i.e., more transparent, and sweeter water is better. The relationship between cleaning rock pools and water quality was unanimous.

"How can a rock pool be found?"

The residents used certain parameters to find rock pools, among which included the presence of soil between the rocks, rock quality (hard and mid-hard rocks), and if rocks were continuous, shattered or presented fissures. Over time, the people have tested and enhanced this perception. In specific cases, these rock pools received human adaptations, e.g., wall built with cement or concrete. Most informants reported that they did not know the origin of the water bodies, whereas others claimed it was "nature's blessing".

\section{Discussion}

Our results identified the aspects of memory incorporated into the population's identity through techniques used to manage local rock pools (Figure 4). Some of these techniques or strategies are part of the collective memory, including traditional knowledge about the conservation and maintenance of rock pools, as well as knowledge acquired throughout the generations. However, the knowledge transmitted was restricted to structural identification and methods for maintaining and improving cleaning during drought periods, among others.

The concept of memory embraces the conservation of past events and people's identity [2]. For centuries, rural populations around the world have been using simple strategies with easily accessible construction and low costs [20]. Among these strategies, rainwater catchment is an important resource that has been used by several communities during long periods of drought [36]. Our results reinforced the relevance of traditional knowledge when facing global warming and threats associated with it. Currently, despite the low use of these ecosystems in dry regions, the collective memory transmitted by ancestors could be strategic insurance for tackling climate change.

The historical records did not reveal when rock pools were first used or emerged. However, this technique arose when the community experience years of prolonged drought. According to one of the most experienced informants in the community,

Page 5/16 
some rock pools have existed since past generations, while others emerged due to needs caused by water shortages. In prolonged droughts scenarios, it is possible to identify the positive impact of these natural reservoirs in the local economy due to easy maintenance and low management costs. However, we need to improve the dialogue between native people and public authorities in order to preserve the culture and popular memory of populations originating from dry land zones.

The presence of lakes, rivers, reservoirs or any other water source, such as rock pools, have been decisive for the emergence of villages, occupation of territories and agricultural development [37], not only in the Brazilian Northeast but throughout the world $[38,39]$. Human development has always been associated with water availability and supply, as it influences human economic activities such as livestock and farming.

Water supply is critical for the economic development of dry land regions. In these regions, there is high demand to access water for agriculture and other economic activities to the irregular water distribution, with rock pools being one method to mitigate this condition [24]. The quest over time and generations for survival and resilience due to extreme and prolonged droughts led populations to search for alternative technologies to support their families, agriculture activities and livestock farming. Thus, the perspective of these populations improved to recognize the main structural aspects present in rock pools, as well as the importance of managing them in order to avoid contamination (visible green color). However, the loss of ancient knowledge could have negatively impacted the local water supply, enhancing the water crisis.

At the beginning of 2007, through the One Million Cisterns Project, communities started progressing socially and economically. In this scenario, cisterns were constructed to improve access to water and keep this resource in good consumption conditions [24]. The use of cisterns became popular in the Rio Direito community, however, in neighboring regions, despite the presence of cisterns for $50 \%$ of the families interviewed, $73 \%$ kept using water from rock pools [e.g. 23]. This result indicates a distinct pattern in the River Direito, where the highest proportion of use is attributed to cisterns. Perennial sources are an excellent alternative for this population; however, this alternative arises to the detriment of maintaining and handling rock pools and transferring knowledge about them between generations.

Shallow water bodies such as rock pools are exposed to allochthonous contributions such as animals waste, twigs, and leaves. These factors could have contributed to the decrease in water quality of rock pools located closer to the village, which presented changes that are common in shallow and temporary water bodies, e.g., change from clear to turbid waters and dominance of harmful cyanobacteria [40]. In semiarid regions, harmful cyanobacteria might be favored due the high temperatures and high nutrients concentrations, among other factors [e.g. 41]. After the prolonged drought periods, a transient or ghost state could arised, characterized by water bodies in a longer transient state, where growing conditions for macrophytes or phytoplankton would be more favorable $[42,43]$.

Among the main changes in water quality of rock pools and other shallow water bodies, fluctuations in water level and processes associated with artificial eutrophication and human occupation can cause shifts from clear to turbid states [40,44]. Some interviewees indicated that water level fluctuation could be a good strategy to decrease the recurrence of harmful cyanobacterial blooms, but successful management depends on the morphological characteristics of the ecosystems [e.g. 45].

Drought has been influencing water levels and, consequently, nutrient concentrations favoring the eutrophication process and cyanobacterial blooms $[46,47,48,49]$. The presence of cyanobacteria is especially problematic in Northeastern Brazil as it is the first place where the association between cyanobacterial blooms and human deaths due to water contamination by cyanotoxins was recorded [50,51]. Cyanobacterial blooms produce cyanotoxins, including saxitoxins, which likely has induced the Congenital Zika Syndrome (ZIKV) [52]. Recently, the ZIKV has emerged as a serious problem in this region, with a high index of microcephaly coinciding with extreme drought periods [52].

\section{Conclusion}

In summary, the loss of management techniques between generations and the loss of interest regarding rock pools in this population contributed to the expansion of pollution on a spatial scale, especially the eutrophication process and, consequently, the dominance of toxin-producing cyanobacteria. Although cisterns and other alternative water sources have improved people's

Page 6/16 
access to drinking water, the importance of rock pools as water sources should not be neglected. With respect to traditional knowledge, the Rio Direito community still remembers the methods transmitted by the past generations, but with increased popularity of cisterns, the transmission of traditional knowledge has decreased between families and generations, presenting a serious social problem for this region characterized by extreme and prolonged droughts. The Rio Direito community has a valuable role in transmitting information and keeping memories and identity of traditional communities in dry land regions.

\section{References}

1. Miranda, JC. The memory in s. Augustine: Memoria Rerum, Memoria Sui, Memoria Dei. Hvmanitas LIII: 1-23. 2001. Available from: https://www.uc.pt/fluc/eclassicos/publicacoes/ficheiros/humanitas53/11_Miranda.pdf

2. Morel PM, Lyon ENS. Memória e caráter: Aristóteles e a história pessoal. Dissertatio. 2009;30:11-44. https://doi.org/10.15210/dissertatio.v30i0.8790

3. Agnew V. Diaspora, memory, and identity: a search for home. Toronto: University of Toronto Press; 2005.

4. Rose, DB. Reports from a Wild Country: Ethics for Decolonisation. Sydney: University of New South Wales Press; 2004.

5. Andersen C. 'Exploring Aboriginal identity in Australia and building resilience'. In: Gabbay Lk (ed.), Indigenous, Aboriginal, Fugitive and Ethnic Groups Around the Globe, In Tech Open Limited, United Kingdom; 2019.

6. Toussaint S, Sullivan P, Yu S. Water Ways in Aboriginal Australia: An Interconnected Analysis. Anthropol Forum. 2005;15(1):61-74. https://doi.org/10.1080/0066467042000336715

7. Oyama MD, Nobre CA. A new climate-vegetation equilibrium state for tropical South America. Geophys Res Lett. 2003;30(23):1-4. https://doi.org/10.1029/2003GL018600

8. Lopes IUG, Santos SM, Leal BG, Melo JMM. Variação do índice de aridez e tendência climática à desertificação para a região semiárida do nordeste brasileiro. R Bras Geogr Fís. 2017;10(4):1014-1026.

https://doi.org/10.26848/rbgf.v10.4.p1014-1026

9. Tabarelli M, Leal IR, Scarano FR, Silva JMC. Caatinga: legado, trajetória e desafios rumo à sustentabilidade. Sci Cul. 2018;70(4):25-29. https://doi.org/10.21800/2317-66602018000400009

10. Alvares CA, Stape JL, Sentelhas PC, Gonçalves JLM, Sparovek G. Köppen's climate classification map for Brazil. Meteorol Zeitschrift. 2013;22:711-728. http://doi.org/10.1127/0941-2948/2013/0507

11. Finan TJ, Nelson DR. Making rain, making roads, making do: public and private adaptations to drought in Ceará, Northeast Brazil. Clim Res.2001;19(2):97-108. https://doi.org/ 10.3354/cr019097

12. Ab'saber AN. Sertões and Sertanejos: a suffering human geography. Estud Av. 1999;13:1-55. http://dx.doi.org/10.1590/S0103-40141999000200002

13. Santos TP. Análise da precipitação mensal do município de Vitória da Conquista-Ba entre os anos de 1982 a 2016 em episódios dos fenômenos el niño e la niña. Geoaraguaia. 2018;8(3):1-22.

14. Marengo JA, Bernasconi M. Regional differences in aridity/ drought conditions over Northeast Brazil: present state and future projections. Clim Chang. 2015;129:103-115. https://doi.org/10.1007/s10584-014-1310-1

15. IPCC. Contribution of Working Group I to the Fourth Assessment Report of the Intergovernmental Panel on Climate Change. Solomon S, Qin D, Manning M, Chen Z, Marquis M, Averyt KB, Tignor M, Miller HL (eds). Cambridge Univ Press, Cambridge, UK; 2007.

16. Ragab R, Prudhomme C. Climate change and water resources management in arid and semi-arid regions: prospective and challenges for the 21st century. Biosyst Eng. 2002;81(1):3-34. https://doi.org/10.1006/bioe.2001.0013

17. Adger WN, Hug S, Brown K, Conway D, Hulme M. Adaptation to climate change in the developing world. Prog Dev Stud. 2003;3(3):179-195. https://doi.org/10.1191/1464993403ps060oa

18. DFID. Sustainable Livelihoods and Poverty Elimination: Background Briefing; 1999.

19. Mancal A, Lima PVPS, Khan AS, Mayorga MIDO. À espera da seca que vem: capacidade adaptativa em comunidades rurais do semiárido. Rev Bras Estud Popul. 2016;33(2):257-281. 
20. Lima AF, Silva DR, Sampaio JLF. As tecnologias sociais como Estratégia de convivência com A escassez de água no Semiárido cearense. Conex Ci e Tecnol. 2011;5(3):9-21.

21. Pereira TMS, Santiago MS, Silva JAL, Moura DC. Tanques de pedra: tecnologia social voltada a gestão hídrica. Rev Bras Meio Ambiente. 2018;4(1):1-8.

22. Brendonck $L$, Jocque $M$, Hulsmans A, Vanschoenwinkel B. Pools 'on the rocks': freshwater rock pools as model system in ecological and evolutionary research. Limnetica. 2010;29(1):1-16. https://doi.org/10.23818/limn.29.03

23. Almeida HA, Cabral LN. Água e desenvolvimento sustentável na zona rural das microrregiões do Agreste e Curimataú da Paraíba. Rev Geogr. 2013;30(3):82-97.

24. Ribeiro CS, Oliveira GG. The water issue in Bahia's semiarid region: conflicts over water use and social technologies for rainwater use. Rev CESLA. 2019;23:355-381.

25. Andrade ARS, Pinheiro GM, Andrade EKP, Santos MKS, Campelo KBF. Principais sistemas de captação de água de chuva: Uma forma de diminuir os efeitos das secas prolongadas no município de Lagoa do Ouro, Pernambuco. Em Extensão. 2017;16(2):101-128. https://doi.org/10.14393/REE_v16n22017_art05

26. Mascarenhas JC, Beltrão BA, Junior LCS, Morais F, Vam Mendes JLF, Menezes R, Souza BI. Manejo sustentável dos recursos naturais em uma comunidade rural do semiárido nordestino. Cad Logepa. 2005;6(1):41-54.

27. Cirilo JA. Public Water Resources Policies for the Semiarid. Estud Av. 2008;22(63):61-82. https://doi.org/10.1590/S010340142008000200005

28. Alves JJA, Souza EM, Araújo MA. Estudo descritivo da tipologia turística do município de Cabaceiras-Paraíba. Cad Virtual Tur. 2008;8(3):86-103.

29. Poole HH, Atkins WRG. Photo-electric measurements of submarine illumination throughout the year. J Mar Biol Ass India. 1929;16:297-324. https://doi.org/10.1017/S0025315400029829

30. Cole G. Text book of limnology. Waveland Press, Illinois; 1994.

31. Utermohl H. Zur Vervolkomnung der quantitative Phytoplankton: Methodik. Mitteilungen. Inte Ver Theor Angew Limnol. 1958;9:1-38.

32. Lund JWG, Kipling C, Lecren ED. The inverted microscope method of estimating algal numbers and the statistical basis of estimations by counting. Hydrobiologia. 1958;11:143-170. https://doi.org/10.1007/BF00007865

33. Sun J, Liu D. Geometric models for calculating cell biovolume and surface area for phytoplankton. J Plan Res. 2003;25:1331-1346. https://doi.org/10.1093/plankt/fbg096

34. Hillebrand H, Dürselen CD, Kirschtel D, Pollingher D, Zohary T. Biovolume calculation for pelagic and benthic microalgae. J Phycol. 1999;35:403-424. http://doi.org/10.1046/j.1529-8817.1999.3520403.x

35. Marques JGW. Pescando Pescadores: Etnoecologia Abrangente no Baixo São Francisco alagoano. NUPAUB-USP. São Paulo, Brasil; 1995.

36. Menezes R, Souza Bi. Sustainable Management of Natural Resources in a Rural Community of the Northeastern Semiarid. Cad Logepa. 2011;6: 41-54.

37. Silvestre, MED. Freshwater in Brazil: reasons for a new policy. Unpublished Master's Dissertation, Postgraduate Program in Development and Environment, Federal University of Ceará, Fortaleza; 2002.

38. Vuorinen HS. Water and health in antiquity: Europe's legacy. In Environmental History of Water -Global view of community water supply and sanitation. Editado por Juuti PS, Katko TS, Vuorinen HS. London: IWA Publishing; 2007.

39. Angelakis A, Zheng X. Evolution of water supply, sanitation, wastewater, and storm water technologies globally. Water. 2015; 7(2): 455-63. https://doi.org/10.3390/w7020455

40. Burks R, Mulderij G, Gross E, Jones Ig, Jacobsen L, Jeppesen E, Donk EV. Center stage: the crucial role of macrophytes in regulating trophic interactions in shallow lake wetlands. In: Wetlands: Functioning, Biodiversity Conservation, and Restoration [Internet]. Bobbink R, Beltman B, Verhoeven JTA, Whigham DF, editors. Springer, Berlin Heidelberg; 2006.

41. Moura AN, Aragão-Tavares NK, Amorim CA. Cyanobacterial blooms in freshwater bodies from a semiarid region, Northeast Brazil: A review. J Limnol. 2018;77(2):179-188. https://doi.org/ 10.4081/jlimnol.2017.1646

Page $8 / 16$ 
42. Van Geest GJ, Coops H, Scheffer M, Van Nes EH. Long transients near the ghost of a stable state in eutrophic shallow lakes with fluctuating water levels. Ecosystems. 2007;10:36-46. https://doi.org/10.1007/s10021-006-9000-0

43. Scheffer M, Van Nes EH. Shallow lakes theory revisited: various alternative regimes driven by climate, nutrients, depth and lake size. Hydrobiologia. 2007;584,455-466. https://doi.org/10.1007/s10750-007-0616-7

44. Scheffer M. Ecology of shallow lakes. Chapman and Hall, London; 1998.

45. Bakker ES, Hilt S. Impact of water level fluctuations on cyanobacterial blooms: management options. Aquat Ecol. 2015;50(3). https://doi.org/10.1007/s10452-015-9556-x

46. Bouvy M, Moica R, Oliveira S, Marinho M, Beker B. Dynamics of a toxic cyanobacterial bloom (Cylindrospermopsis raciborskii) in a shallow reservoir in the semi-arid region of northeast Brazil. Aquatic Microbi Ecol. 1999;20(3):285-297. https://doi.org/10.3354/ame020285

47. Wiegand MC, Piedra JIG, Araújo JC. Vulnerability to eutrophication of two tropical lakes with wet (Cuba) and semiarid (Brazil) climates. Eng Sanit Ambient. 2016;21(2):415-424. https://doi.org/10.1590/s1413-41522016139527

48. Costa RL, Todeschini T, Ribeiro MJP, Oliveira MT. Florações de cianobactérias potencialmente tóxicas em tanques de pisciculturas da região centro sul do estado de Mato Grosso. Biodiversidade. 2017;16(1):1-13.

49. Silva EB, Araújo Neto JR, Lima BP. Similarity of eutrophication of surface waters of the upper Jaguaribe basin, Ceará. Eng. Agric. 2017;25(4):1-8. https://doi.org/10.13083/reveng.v25i4.800

50. Pouria S, Andrade A, Barbosa J, Cavalcanti RL, Barreto VT, Ward CJ, Preiser W, Poon GK, Neild GH, Codd GA. Fatal microcystin intoxication in haemodialysis unit in Caruaru, Brazil. Lancet. 1998;4(352):6-21. https://doi.org/10.1016/s01406736(97)12285-1

51. Komárek J, Kastovsky J, Jezberová J. Phylogenetic and taxonomic delimitation of the genus Aphanothece cyanobacteria and description of the genus Anathece. Nov. Eur J Phycol. 2011;46(3):315-326.

https://doi.org/10.1080/09670262.2011.606373

52. Pedrosa CSG, Souza LRQ, Lima CVF, Ledur PF, Karmirian K, Gomes TA, Barbeito-Andes J, Costa MN, Higa LM, Bellio M, Lara FA, Tanuri A, Garcez PP, Prata-Barbosa A, Tovar-Moll F, Molica RJR, Rehen SK. The cyanobacterial saxitoxin exacerbates neural cell death and brain 2 malformations induced by Zika virus. BioRxi. 2019;1:1-23. https://doi.org/10.1101/755066

53. Silva AS, Brito LTL. Rainwater harvesting: Environmental sustainability in the Brazilian semi-arid. Written for the Rainwater Training course at the XXXV Brazilian Congress of Agricultural Engineering - João Pessoa - PB. 2006. [https://ainfo.cnptia.embrapa.br/digital/bitstream/CPATSA/33856/1/OPB649.pdf

54. Gnadlinger J. Rumo a um Padrão Elevado de Qualidade de Água de chuva coletada em cisternas no Semi-Árido Brasileiro. $6^{\circ}$ Simpósio Brasileiro de Captação e Manejo de Água de Chuva. Belo Horizonte, Minas Gerais. 2007. [http://www.abcmac.org.br/files/simposio/6simp_gnadlinger_rumo.pdf].

\section{Tables}

Table 1. Environmental data of 20 rock pools in the Northeast of Brazil. 


\begin{tabular}{|c|c|c|c|c|c|c|c|c|c|}
\hline RockPools & $\begin{array}{l}\text { Length } \\
\text { (m) }\end{array}$ & $\begin{array}{l}\text { Width } \\
\text { (m) }\end{array}$ & $\begin{array}{l}\text { Air } \\
\text { Temperature } \\
\left({ }^{\circ} \mathrm{C}\right)\end{array}$ & $\begin{array}{l}\text { Water } \\
\text { transparency } \\
\text { (m) }\end{array}$ & $\begin{array}{l}\text { Euphotic } \\
\text { zone } \\
(\mathrm{m})\end{array}$ & $\begin{array}{l}\text { Dissolved } \\
\text { oxygen } \\
\left(\mathrm{mg} \cdot \mathrm{L}^{1}\right)\end{array}$ & $\begin{array}{l}\text { Water } \\
\text { Temperature } \\
\left({ }^{\circ} \mathrm{C}\right)\end{array}$ & $\mathrm{pH}$ & $\begin{array}{l}\text { Biomass } \\
\left(\mathrm{mg} . \mathrm{I}^{-1}\right)\end{array}$ \\
\hline I & 17.4 & 4.4 & 26 & 0.5 & 1.5 & 16.2 & 23.9 & 5.8 & 22.9 \\
\hline II & 43.2 & 10 & 27 & 0.5 & 1.6 & 20 & 29.5 & 9.3 & 269.5 \\
\hline III & 5 & 2.3 & 27.2 & 0.3 & 0.9 & 4.4 & 27.8 & 6.9 & 0.04 \\
\hline IV & 4 & 2.6 & 25.8 & 0.5 & 1.5 & 6.2 & 27.8 & 7.4 & 0.002 \\
\hline V & 6 & 1 & 25.7 & 0.7 & 2.1 & 6.3 & 25.1 & 6.3 & 0.001 \\
\hline $\mathrm{VI}$ & 6.2 & 3.2 & 29.6 & 0.2 & 0.7 & 4.8 & 29.6 & 6.2 & 0.006 \\
\hline VII & 7.2 & 5.7 & 29.5 & 0.5 & 1.5 & 5.6 & 31.1 & 6.7 & 2366.2 \\
\hline VIII & 13 & 4 & 31.6 & 1 & 3 & 4.4 & 30.6 & 6.4 & 0.04 \\
\hline IX & 8.5 & 1.4 & 32.3 & 0.5 & 1.5 & $-*$ & 28.9 & 7.9 & 0.07 \\
\hline$x$ & 6.2 & 1.8 & 32 & 0.3 & 1 & - & 30 & 10.3 & 0.02 \\
\hline$X I$ & 33.4 & 9.7 & 33 & 0.6 & 2 & - & 32.9 & 9.4 & 0.01 \\
\hline XII & 13.1 & 4.4 & 34.6 & 0.6 & 1.8 & - & 33.4 & 8.4 & 0.01 \\
\hline XIII & 10.9 & 3.9 & 29 & 1.5 & 4.5 & - & 30.8 & 7.4 & 0.2 \\
\hline XIV & 7 & 2.8 & 34.8 & 0.21 & 0.6 & - & 31.1 & 7.2 & 0.004 \\
\hline$X V$ & 6.7 & 3.3 & 33.9 & 0.5 & 1.5 & - & 28.6 & 7.4 & 0.3 \\
\hline $\mathrm{XVI}$ & 14.8 & 1.7 & 32.4 & 0.7 & 2.1 & - & 30.5 & 7 & 0.07 \\
\hline XVIII & 14 & 4 & 36.7 & 0.5 & 1.5 & - & 32.6 & 7.3 & 39.3 \\
\hline XIX & 3 & 1.7 & 35.8 & 0.4 & 1.2 & - & 34.6 & 7.6 & 0.02 \\
\hline$X X$ & 4.9 & 2.6 & 30.2 & 0.3 & 0.9 & - & 32.2 & 9.3 & 0.05 \\
\hline
\end{tabular}

Table 2. Knowledge and Use of Rock pools (Comparative Cognition). 


\begin{tabular}{|c|c|c|c|c|}
\hline $\begin{array}{l}\text { CONSTRUCTION } \\
\text { / ORIGIN OF } \\
\text { ROCK POOLS }\end{array}$ & $\begin{array}{l}\text { USE OF } \\
\text { ROCK } \\
\text { POOLS IN } \\
\text { PAST }\end{array}$ & $\begin{array}{l}\text { USE OF } \\
\text { ROCK POOLS } \\
\text { IN PRESENT }\end{array}$ & MANAGEMENT & REFERENCES \\
\hline $\begin{array}{l}\text { "Between a rock } \\
\text { and another. } \\
\text { then you dig and } \\
\text { there is the } \\
\text { tank." } \\
\text { (Anonymous 37) }\end{array}$ & Drink & Animal use & $\begin{array}{l}\text { Almost no longer exist. the } \\
\text { cleaning is done by some } \\
\text { community members. }\end{array}$ & $\begin{array}{l}\text { Rock pools are formed where there are } \\
\text { natural holes in the crystalline that rises } \\
\text { to the surface (so-called "lajedos") [36]. }\end{array}$ \\
\hline $\begin{array}{l}\text { "Dig until reach } \\
\text { the stone. when } \\
\text { necessary use } \\
\text { fire to break the } \\
\text { stones." } \\
\text { (Anonymous 73) }\end{array}$ & Cook & Washing & $\begin{array}{l}\text { With the arrival of the } \\
\text { cisterns. this concern no } \\
\text { longer exists. }\end{array}$ & $\begin{array}{l}\text { The rock poolsare naturally originated in } \\
\text { the cracks of rocky outcrops of } \\
\text { crystalline base and enable storage of } \\
\text { rainwater [53]. }\end{array}$ \\
\hline $\begin{array}{l}\text { "When there is a } \\
\text { stone together } \\
\text { with other and is } \\
\text { made with } \\
\text { shooting } \\
\text { (dynamite)". ( } \\
\text { Anonymous 80) }\end{array}$ & Agricultural & Agricultural & $\begin{array}{l}\text { The care with cleaning of } \\
\text { the rock pools are in: } \\
\text { exhaust the little dirty water } \\
\text { left. sweep and wash. so } \\
\text { when it rains gather clean } \\
\text { water. Also cover with } \\
\text { stones. pieces of wood. to } \\
\text { avoid water evaporation. }\end{array}$ & $\begin{array}{l}\text { Also called "Cauldron" by Gnadlinger } \\
\text { [54] rock pools are natural cracks in the } \\
\text { rock. deepened by the rural population } \\
\text { itself. which removes dirt and gravel } \\
\text { from the deepest part. clearing it. This is } \\
\text { an excellent reservoir to store rainwater } \\
\text { for human. animal and agricultural use" } \\
\text { [20]. }\end{array}$ \\
\hline $\begin{array}{l}\text { "Is a work of } \\
\text { nature that digs } \\
\text { the sand of the } \\
\text { stones and } \\
\text { make up the } \\
\text { rock pools" } \\
\text { (Anonymous 44) }\end{array}$ & & $\begin{array}{l}\text { Little used for } \\
\text { domestic } \\
\text { consumption. }\end{array}$ & & $\begin{array}{l}\text { Example of technology that enables the } \\
\text { increase in water supply not only for } \\
\text { human purposes but for irrigation. } \\
\text { animal consumption favouring } \\
\text { sustainable rural development [23]. }\end{array}$ \\
\hline
\end{tabular}

Table 3. Community perception / cognition comparative. 


\section{Traditional Knowledge \\ Information according to limnological analysis}

"The more transparent the better the water" (anonymous, 48.)

Overall, low values of water transparency were observed, ranging from a minimum of 0.21 to a maximum of $1.5 \mathrm{~m}$, where the lower value identified for the rock pool XIV and the highest in the rock pool XIII. These characteristics showed that most rock pools are turbid.

"By taste, if it is sweet it is good" (anonymous, 74)

Most environments analyzed showed low transparency values, with cyanobacteria blooms, showing that the water may be improper for consumption in most cases.

"The best water is the one that has a green paste, the water gets colder and cleaner" (anonymous, 48)

"By color, the more greenish is not good" anonymous, 73)

The presence of the Chara martiniana Wallman (Characeae) in at least two rock pools, indicated a good water quality.

In the twenty environments analyzed, cyanobacteria harmful blooms were found in 2 rock pools. On the other hand, the presence of the harmful cyanobacteria was found in all rock pools, indicating the optimum of the occurrence conditions.

\section{Figures}



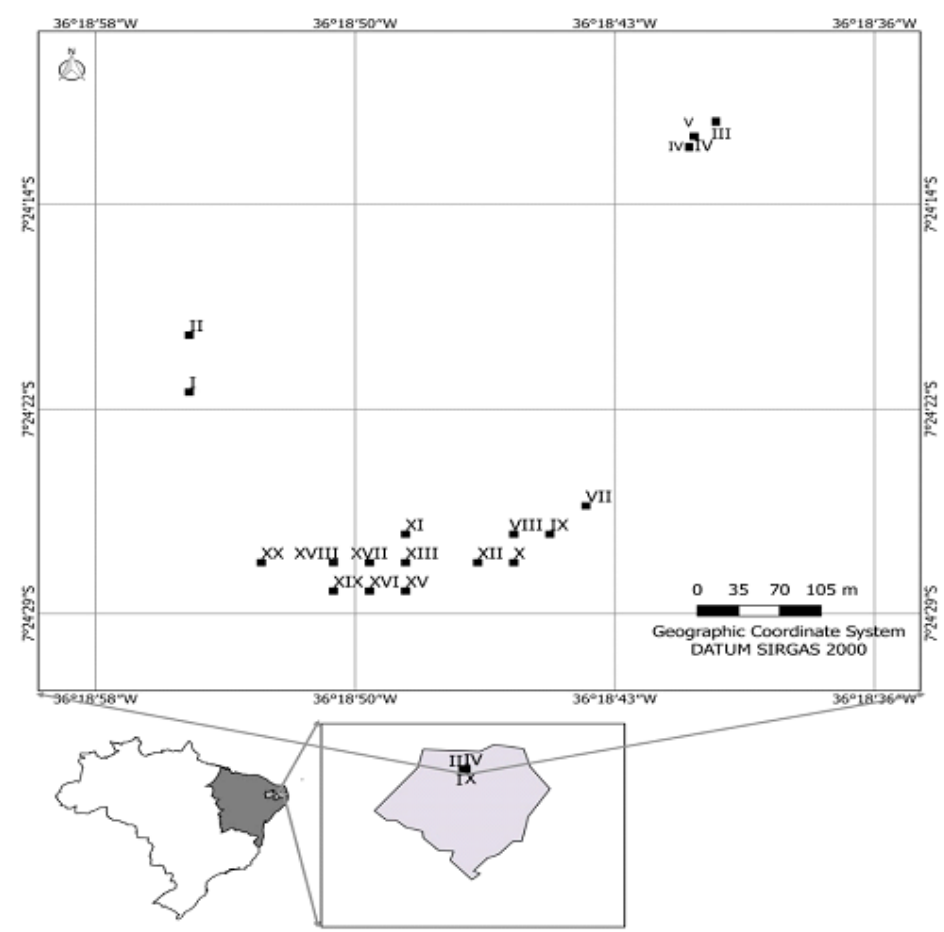

Legend

$\square$ Brazil $\square$ Municipality of Cabaceiras : II : IX : VIII : XIII : XVI - XX

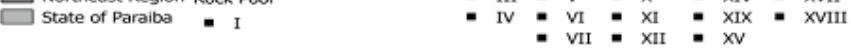

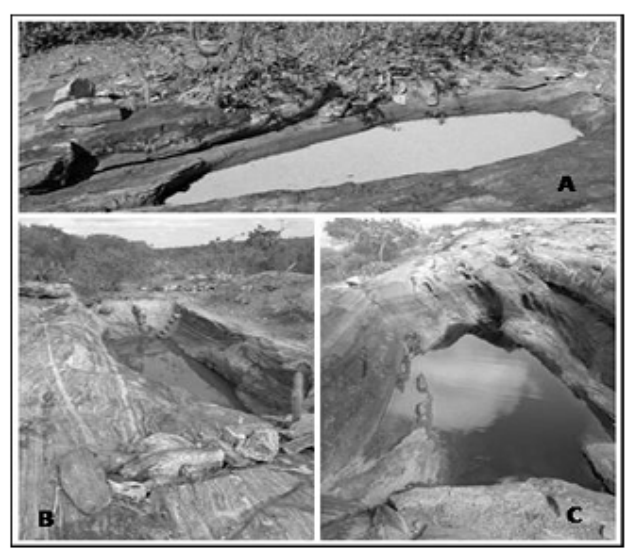

Figure 1

Location of the Rock Pools. Details of the morphology of the rock pools (A, B, C) (Cabaceiras, Paraíba, Brazil). 

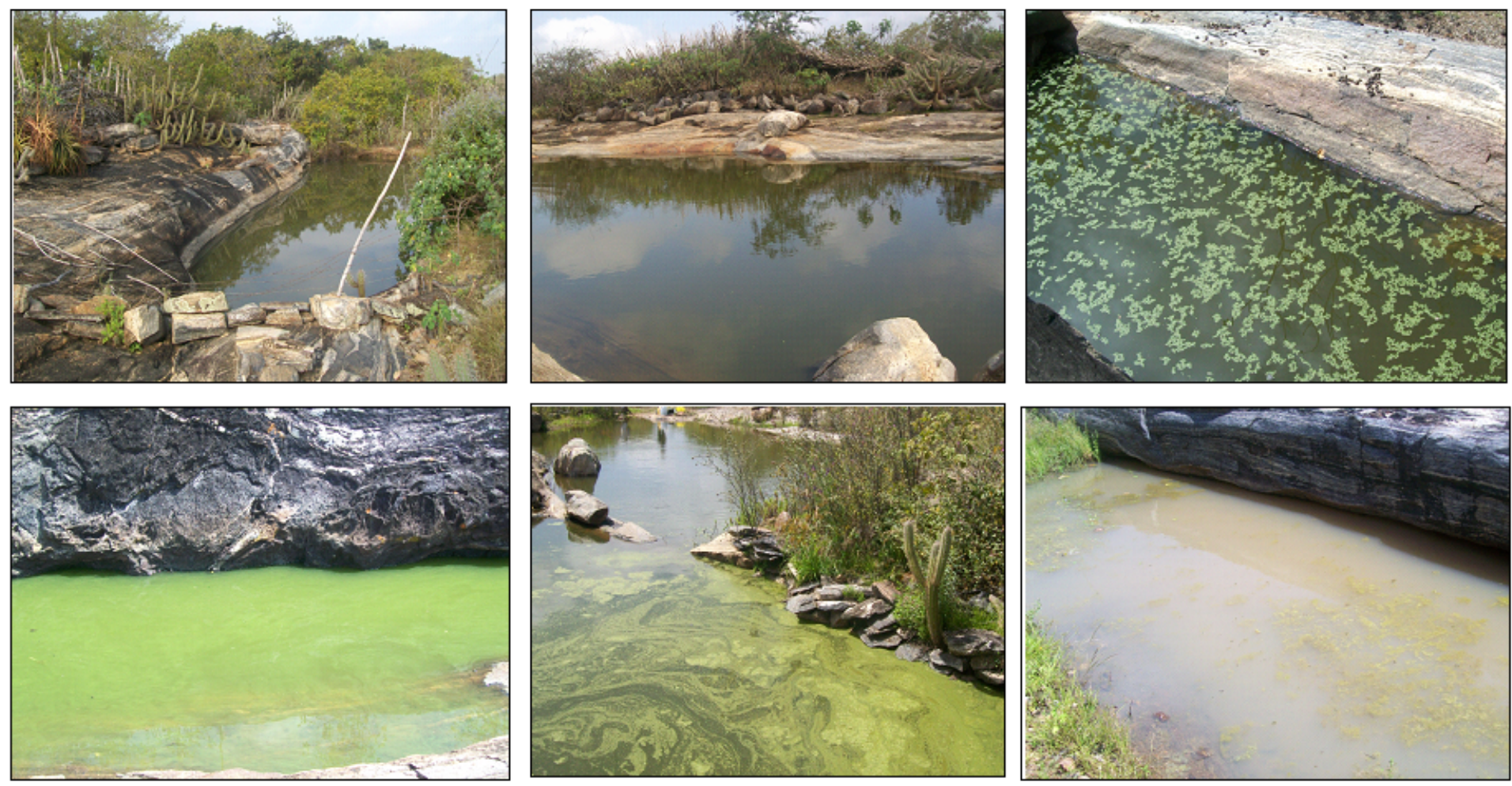

Figure 2.

\section{Figure 2}

Seaweed Flowering rock pools (Cabaceiras, Paraíba, Brazil). 

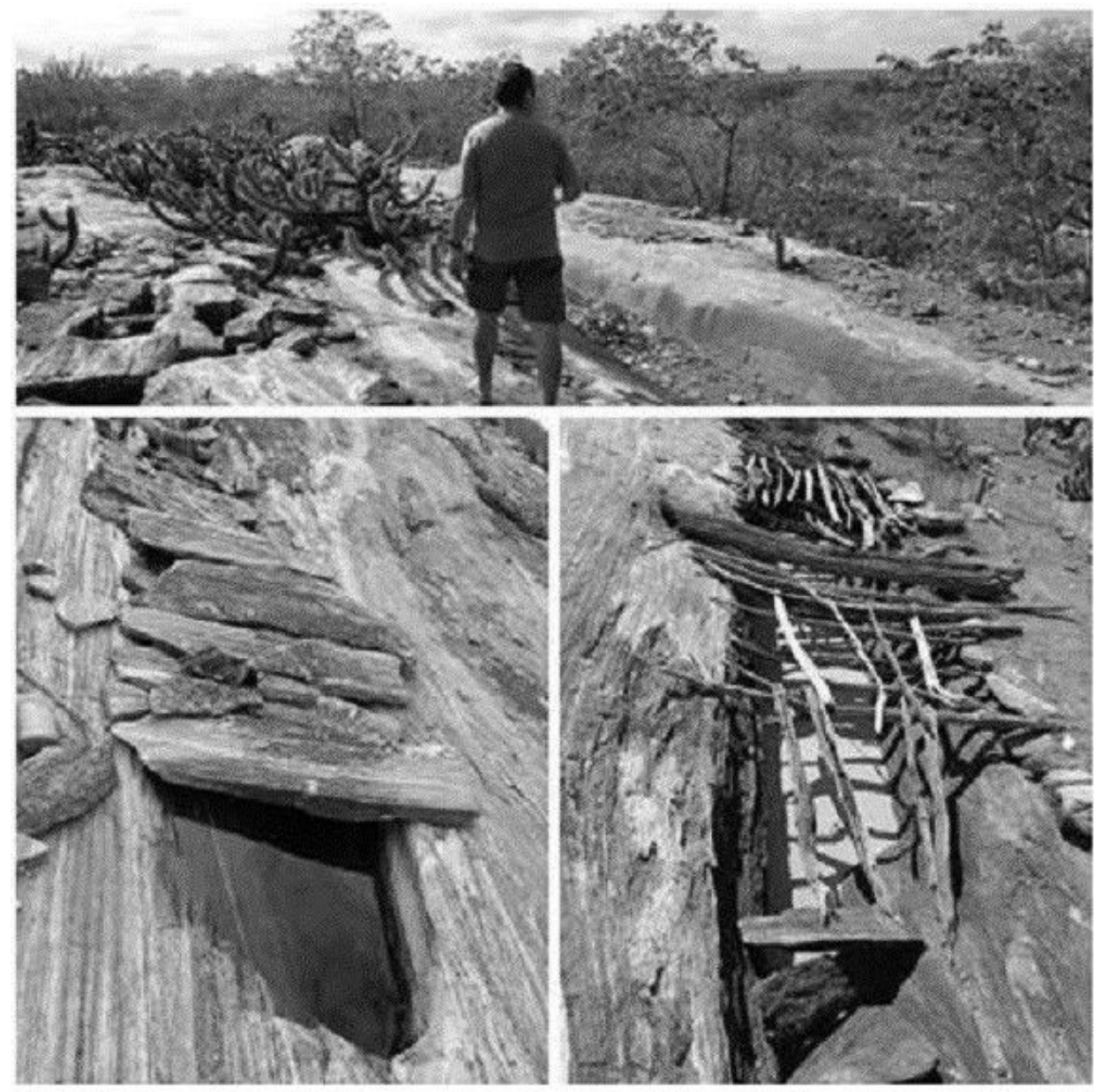

Figure 3 .

\section{Figure 3}

Management strategy used by community residents to prevent the evaporation and contamination of natural pools (Cabaceiras, Paraíba, Brazil). 
Historical Memory: ancestral knowledge of the management of the Rock Pools

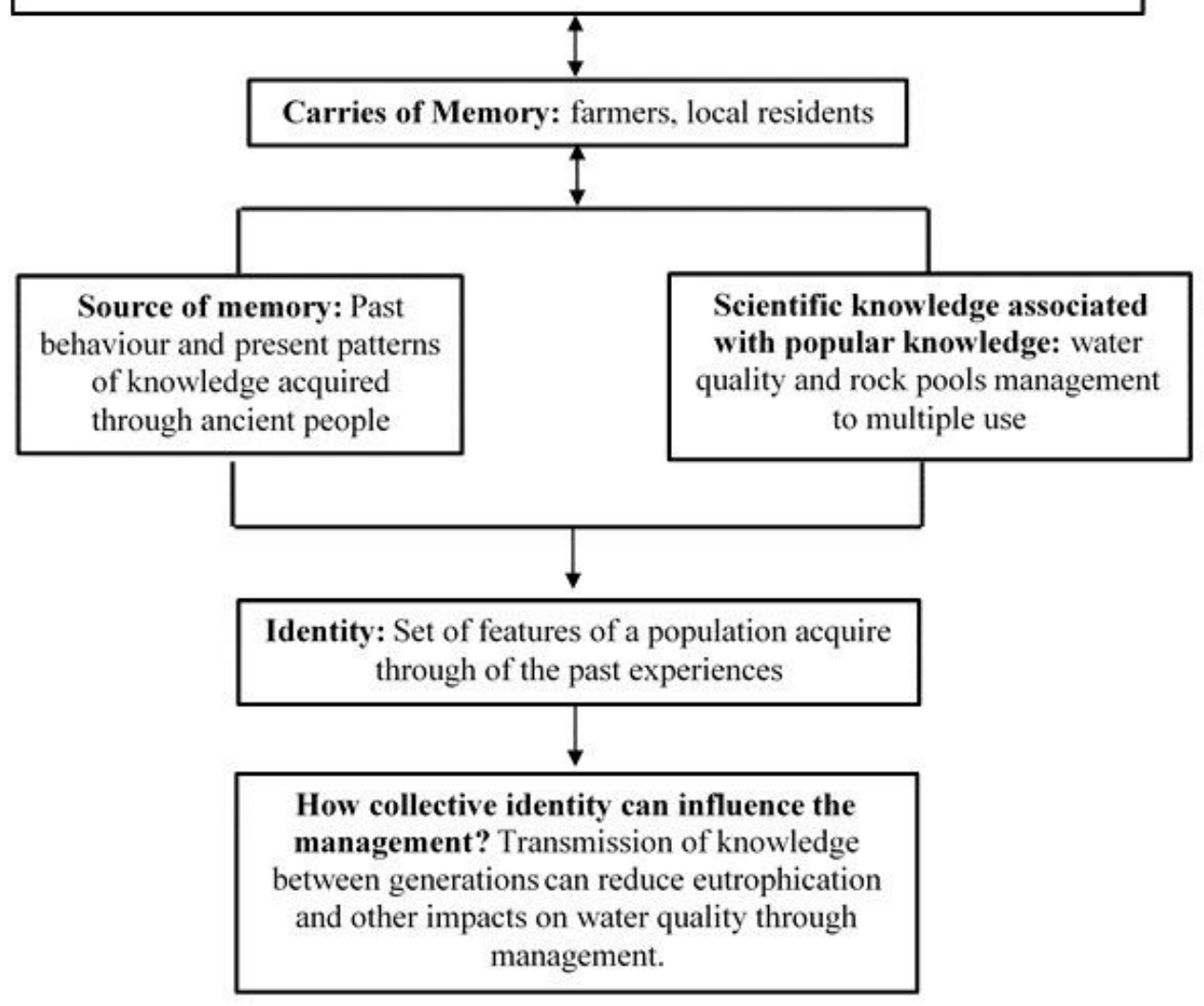

Figure 4.

\section{Figure 4}

Schematic concept of the memory transmission mechanism through of a Model Community (Paraiba, Brazil). 